\title{
A INSTITUIÇÃO DO MANDĀTO NAS SOCIEDADES LIMITADAS
}

\author{
De Plácido e Silva \\ Professor da Faculdade de Direito da \\ Universidade do Paraná
}

1. A instituição do mandato, em princípio, salvo o que concerne às exigências pertinentes à capacidade do mandante, e assente no direito de liberdade de contratar, é livre. Cabe ao mandante escolher mandatário, por sua preferência, sem que se possa restringir a livre escolha, firmada, exclusivamente, na confiança depositada na pessoa que o vai substituir na prática de atos jurídicos de seu interêsse.

No entanto, a regra sofre exceções. Para os casos judiciais, sòmente se permite a outorga do mandato em pessoa devidamente habilitada para a procuratoria judiciária. E, nas sociedades por ações, o mandato simplesmente se permite se dado à pessoa que igualmente possua a qualidade de acionista como o mandante, segundo é a norma do $\S 1 .^{\circ}$ do art. 91, do Decreto-lei n. ${ }^{0} 2.627$, de 26 de setembro de 1940.

Por esta razão, nestas circunstâncias, a pessoa sofre restrição à liberdade de convenção, visto que não será legítimo o mandato que outorgar em infração aos preceitos legais estabelecidos, que impõe a escolha em pessoa que conduza os requisitos ou as condições legais exigidas.

Mas, determinando o artigo 18, do Decreto n. ${ }^{0} 3.708$, de 10 de janeiro de 1919, que nas sociedades por cotas de responsabilidade limitada sejam observadas, no que não fôr regulado 
por esta lei e na parte aplicável, as disposições da lei das sociedades anônimas, pode o sócio cotista passar mandato à pessoa não cotista, para representá-lo em assembléias ou reuniões das mesmas sociedades?

Evidentemente que pode. Nenhuma lei o proíbe. 0 cotista de uma sociedade por cotas de responsabilidade limitada pode comparecer às reuniões de assembléia, dispostas na forma contratual, por pessoas de sua confiança, sejam ou não sejam cotistas da mesma sociedade, desde que expressa proibição não se firme na lex privata da sociedade. Sòmente se, conforme regra fixada no contrato, ficou defeso ao sócio a livre instituição do mandato, em qualquer pessoa, exigindo-se a condição ou qualidade de sócio, não terá êle o direito de eleger para seu representante pessoa estranha à sociedade.

No Código Comercial, no Decreto que criou as sociedades por cotas ou em qualquer outra Lei, não há disposição que ved ao sócio cotista fazer-se representar nas reuniões de assembléias gerais da sociedade, por meio de mandatário, afim de que, por seu legítimo representante, participe das reuniões, delibere, aprovando ou desaprovando as medidas submetidas à apreciação e decisão dos presentes. $\mathrm{E}$ igualmente, de modo claro e inequívoco, nenhuma regra legal cerceia o direito do cotista de escolher livremente o mandatário dêle, mesmo que não possua a qualidade de consócio.

Dêsse modo, para sua validade, o mandato instituido para representação junto às sociedades por cotas não tem como requisito a condição de ser cotista o mandatário, porque as sociedades por cotas, em que pese o disposto no art. 18 do Decreto 3.708 , de 1919, não se acham sob o mesmo regime das sociedades anônimas.

Embora as sociedades por cotas de responsabilidade limitada não se identifiquem ou se igualem às sociedades ditas de pessoas, não se confundem nem se igualam às sociedades anônimas, chamadas de sociedades de capitaes; formam gênero especial, apresentando-se como tipo intermediário entre as duas espécies de sociedades, com os definidos característicos que lhes são atribuídos por lei. 
2. Tôda controvérsia suscitada acêrca da representação do cotista perante a sociedade por mandato convencional, outorgado a estranhos, promana da regra disposta no art. 18 do decreto $n .^{\circ} 3.708$, de 10 de janeiro de 1919.

E a regra em referência é que:

"Art. 18. Serão observadas quanto às sociedades por cotas de responsabilidade limitada, no que não fôr regulado no estatuto social, e na parte aplicável, as disposições da lei das sociedades anônimas".

Mas, em se analisando o próprio teôr legal, claramente se verificarà que a norma estabelecida não ampara a conclusão de ser defeso ao sócio cotista a instituição de mandato a pessoas estranhas à sociedade, afim de que nela o represente, quando impedido de pessoalmente o fazer.

O princípio instituido pelo $\S 1 .^{\circ}$ do art. 91 da lei das sociedades anônimas, mesmo que omisso o contrato ou estatuto social da sociedade por cotas, não é aplicável por imposição do artigo 18 do decreto 3.708 .

Em relação às sociedades anônimas a proíbição é taxativa. Nem mesmo os acionistas, por deliberação unânime, poderiam estabelecer, nos estatutos da sociedade, permissão para qualquer representação ou instituição de mandato, que contrarie o preceito. Sòmente quem prove ou quem tenha a qualidade de acionista pode comparecer como mandatário nas assembléias gerais das sociedades anônimas. $\mathrm{E}$ todo preceito estatutário que infrinja a regra legal é inoperante. $\mathrm{E}$ nulos, pleno jure, serão todos os atos executados por mandatários, que não satisfaçam a condição legal.

Os sócios cotistas, tendo a faculdade de instituir cláusula permissiva da outorga de mandato a estranhos, por fôrça do que dispõe, in principio, a alínea VII do art. 302 do Código Comercial, o que não se permite ao acionista, não estão adstritos a regra da lei das sociedades anônimas, privativa a êstes e, consequentemente, não aplicável aos primeiros. 
A regra, pois, constante do artigo 18 , a prevalecer nos casos omissos dos contratos das sociedades por cotas não se mostra aplicável em relação à instituição do mandato.

3. $\mathrm{O}$ artigo 18 do decreto $\mathrm{n} .^{\circ} 3.708$ manda em verdade observar as regras instituidas pela lei das sociedades anônimas aos casos omissos no estatuto social das sociedades por cotas, se aplicável ao caso. Dêsse modo, a regra da lei das sociedades anônimas é supletiva ou subsidiária às normas reguladoras das sociedades por cotas, desde que não venha contrariar princípio fundamental que a estas regule.

E', como bem e esclarecedoramente assevera WALDEMAR FERREIRA, insígne comercialista patrício:

"O art. 18 do decreto n. $^{\circ} 3.708$, em suma, não tem a elasticidade que se lhe tem dado. 0 que êle diz, e com clareza, é que, no que não fôr regulado no estatuto social, às sociedades por cotas se aplicarão as disposições da lei das sociedades anônimas. E isso mesmo no que puder ser aplicado. Daí a conclusão a que muitos chegaram de que todos os preceitos referentes às sociedades anônimas se lhe aplicarão, vai um exagêro de hermeneutica, que em errônea se torna.

"Nos pontos em que o contrato social fôr omisso, e como elemento supletivo sendo compatíveis, vigorarão as regras das sociedades anônimas. Nem tudo podem os sócios pactuar. As convenções, em que êles podem se ajustar, são as de natureza privada, que não ofendem nem contrariam normas que só o poder legislativo pode ditar.

"Deixou a lei no seu arbítrio, organizarem a sociedade por cotas à feição da em nome coletivo, ou à imagem e semelhança da anônima. Sociedade hibrida, mixta de uma e outra, pode, mercê de uma concepção original, apresentar-se como uma mescla de ambas, por um feliz ajustamento, harmônico, de orgãos de uma e de outra. Ficou, pois, aos cotista, o encargo de, no contrato social, traçarem o perfil da sociedade, por êste ou aquele modelo, determinando o seu aparelhamento, discriminando os seus orgãos administrativos e lhes precisando as funções. Tal seja o ramo de comércio ou de indústria, a que a sociedade se dedique, tal a forma que mais lhe convenha. 
“Eis aí a principal missão dos sócios no convencionarem o seu contrato social, a lei máxima da sua sociedade, no que não contrariem as leis. Sendo o contrato omisso, no que, podendo por êle ser regulado e objeto de disposição contratual, não fôr, e só nesse caso, lhe aplicarão, na parte aplicável, as disposições da lei das sociedades anônimas.

"Estas disposições podem apenas suprir, completar, integrar, a sociedade por cotas, na sua organização, para que possa funcionar livremente e preencher os seus fins. Não a transformarão em sociedade anônima, e o intuito dos sócios não foi êsse. Nem se lhe aplicarão, sem exceção, tôdas as disposiçñes legais especiais às sociedades anônimas, que ficarão dependendo de expressa deliberação do poder legislativo, como, entre outras, como a de contrair empréstimos mediante a emissão de obrigações ao portador.

"As disposições da lei das sociedades anônimas, em suma, são subsidiárias, não da lei que institui as sociedades por cotas, mas do estatuto ou contrato social destas.

"Assim, se o contrato houver dotado a sociedade de assembléia geral e de conselho fiscal, omitindo, no entanto, o modo de constituição e de função dêstes orgãos, aplicar-se-lhes-ão, sem dúvida, as disposições da lei das sociedades anônimas, relativas tanto à assembléia geral, como ao conselho fiscal.

"A assembléia geral da sociedade por cotas, se de outro modo não dispuzer o contrato social, será convocada como a das sociedades anônimas e deliberará como estas podem deliberar, tendo as mesmas funções e a mesma fôrça. Três serão, do mesmo modo, os fiscais e os suplentes serão de igual número, sendo sua nomeação feita, anualmente, pela assembléia, na sessão ordinária anual, e podendo recair em pessoas que não sejam cotistas. Durará um ano o seu mandato, podendo ser renovado. Este, por certo, o sentido do artigo 18." (Sociedades por cotas, 5a. ed., n. ${ }^{\circ} 170$, pág. 148)

4. 0 artigo 18 do decreto $n .^{\circ} \mathbf{3 . 7 0 8}$, em verdade, não impõe às sociedades por cotas de responsabilidade limitada o respeito a tôdas as regras dispostas para regularidade das socie- 
dades anônimas. Prevalece, simplesmente, no tocante à forma de sua constituição, quando adotada administração similar a das sociedades anônimas, o contrato social é omisso quanto ao funcionamento dessa administração e quanto ao procedimento que se deve seguir para que se cumpram os objetivos de sua adoção.

As disposições da lei das sociedades anônimas aplicáveis aos casos omissos dos contratos das sociedades por cotas têm, pois, influência subsidiária exclusivamente em frente de semelhantes situações. Mas, se a questão é pertinente ao direito ou obrigação do cotista em suas relações com a sociedade, ou se se procura verificar qual a regra que deve ser seguida quando do exercício dêsse direito ou da exigibilidade dessa obrigação, não é a lei das sociedades anônimas que vem suprir a omissão contratual, mas as próprias normas que regulam semelhantes situações dos sócios das demais sociedades comerciais. Temos asFim que buscar as regras que formam o regime das sociedades comerciais comuns, de que a sociedade em nome coletivo é o padrão, porque estão elas, por fôrça do art. $2 .^{\circ}$ da lei que as criou sob regime similar, embora com a limitação das responsabilidades quanto às obrigações decorrentes da formação do capital social.

Assim, embora as sociedades por cotas de responsabilidade limitada, simplesmente chamadas de sociedades limitadas, em razão da responsabilidade restrita que se impõe a seus associados, não sejam, a rigor, sociedades do gênero dito de pessoas, mais se assemelhando a sociedade do tipo das anônimas ou do gênero dito de capitais, não se confundem nem se identificam com a última espécie, para que se subordinem ao regime a que se acham submetidas as anônimas.

Bem por essa razão, a lei que as estabeleceu, acrescendo-as às demais espécies de sociedades, no art. 2..$^{\circ}$, manda que se constituam segundo as regras dispostas para as sociedades comerciais comuns:

"Art. 2.0 0 título constitutivo regular-se-á pelas disposições dos arts. 300 a 302 e seus números do Código Comercial, 
devendo estipular ser limitada a responsabilidade dos sócios à importância total do capital social".

E porque o contrato social, em que se ajustaram os sócios, permita ou adote uma forma de administração similar às sociedades anônimas, não adquirem as sociedades por cotas a feição nem a natureza delas, para que nelas se transformem ou com elas se confundam.

A própria jurisprudência vem em apôio a essas afirmações: "as sociedades por cotas de responsabilidade limitada não se regulam quanto à constituição, pelo decreto 434, de 1891 (antiga lei das sociedades anônimas), aplicando-se-lhe os arts. 300 a 302 e seus números do Código Comercial, ex-vi do art. 2. ${ }^{\circ}$ do decreto 3.708, de 1909." (Brasil Acórdãos, n. ${ }^{\circ} 30.287$, vol. XI)

E se constituição exprime ou significa dar organização ou forma, revela, igualmente, a própria substância, os caracteres que revestem a instituição, que se deriva da composição levada a efeito.

Claro está, pois, que se as sociedades por cotas de responsabilidade limitada são, em essência, sob regime das sociedades comuns, a regra que se impõe à sociedade de regime diverso não lhes pode atingir.

5. Há, mesmo, em relação às sociedades por cotas e às sociedades anônimas, regras e princípios, peculiares a cada espécie, que bem as distinguem e mostram o regime que cabe a cada uma delas.

As ações das sociedades anônimas podem. ser nominativas como podem ser ao portador, podem ser comuns ou podem ser preferenciais. Estas ações sòmente podem ter valor igual, desde que o capital das anônimas é fracionado em porções de valor igual, compondo as próprias ações. As ações são representadas por títulos, que se equiparam aos títulos de crédito, sendo negociáveís.

As cotas das sociedades limitadas serão sempre nominativas e não se representam por títulos. Podem ser de valor igual 
ou pode cada cota ser representada pelo contigente de capital com que se obrigou cada sócio. A transferência ou cessão das cotas importa em modificação do contrato social, sujeitando-se cada cessão ou transferência a registro relativo a essa operação, nas Juntas Comerciais.

As sociedades anônimas sòmente se estabelecem com a existência mínima de sete pessoas capazes. As sociedades por cotas podem organizar-se representada por dois únicos sócios. As sociedades anônimas não se dissolvem pela morte de qualquer acionista. As sociedades por cotas, se o contrato silenciar, está desfeita de pleno jure, entrando em liquidação.

"A morte, a interdição, ou a inabilitação e falência de qualquer dos sócios que figure na firma, salvo convenção em contrário, são também causas de dissolução das sociedades limitadas, porque há nestas sociedades o elemento intuitus personae." (VILEMOR AMARAL, Das Sociedades Limitadas, n. ${ }^{\circ}$ 251, pág. 170)

6. Evidentemente, se o artigo 18 do decreto 3.708, impuzesse às sociedades por cotas o regime das sociedades anônimas, consoante regime que lhe era próprio:

a) Poderiam instituir cotas ao portador ou representadas por títulos nominativos a ordem, consequentemente endossáveis;

b) Não se poderiam organizar com número inferior de sete sócios;

c) Não se dissolveriam, quando omisso o contrato, pela morte, interdição e falência de qualquer de seus sócios;

d) Dela poderiam fazer parte, inicialmente, os menores e interditos.

Nenhuma das regras figurante na lei das sociedades anônimas, que não se mostre aplicável a caso omisso do contrato social das sociedades por cotas de responsabilidade limitada, será convocada para solução de dúvidas ou para regular situações minifestadaș, mesmo que, na sua formação, tenha a sociedade limitada adotado administração ou estabelecido orgãos administrativos similares aos das sociedades anônimas e regulados pela lei que lhe é própria. 
Esta forma admitida pelos cotistas não modifica a substância da sociedade. E sua adoção advem do direito que se assegura a todos de convencionarem livremente, desde que não contrarie a expressa proibição legal.

$0 \S 1 .^{\circ}$ do art. 91 da lei das sociedades anônimas envolve princípio próprio e privativo a esta espécie de sociedade. Não atinge as sociedades por cotas, como não atinge a qualquer outra espécie de sociedade estabelecida pelo Código Comercial.

Em qualquer espécie de sociedade comercial, quando necessária a presença do sócio, para assinar alteração de contrato, para assinar distrato ou para a prática de qualquer ato, a que foi convocado o sócio, pode êste, lìcitamente, fazer-se representar por mandatário, mesmo sem que êste mostre a condição de sócio.

A lei comercial não cria qualquer restrição à outorga de mandatos para exercício dos direitos dos sócios, não consignando qualquer exigência em relação à pessoa que, da confiança do mandante, o venha representar junto à sociedade. A regra do artigo 18 não convoca o princípio da lei das sociedades, não aplicável ao caso.

Assim, os sócios cotistas podem fazer-se representar por mandatários escolhidos entre pessoas não cotistas, para que assistam e defendam seus interêsses junto às sociedades limitadas, mesmo que se tratem de reuniões de assembléias ordinárias ou extraordinárias. Para tanto basta, pois, que lhes defiram poderes especiais e expressos. 